\title{
FATİH ERKOÇOĞLU
}

DR., ANKARA Ü. İLAHIYAT FAKÜLTESİ

e-posta: fatiherkocoglu@hotmail. com

Eyup Baş, Osmanlı Tarih Yazarlarında Toplumsal Sorumluluk Bilinci, ilâhiyât, Araştırma-Inceleme 40, Ankara 2006, (255 s.)

Doç. Dr. Eyup Baş'ın Dil-Tarih İlişkisi Bağlamında Osmanlı Türklerinde Arapça Tarih Yazıcılı̆̆ (XVI. ve XVII. Yüzyıl Örnekleriyle) ${ }^{1}$ isimli doktora çalışmasından sonra hazırlamış olduğu yeni eseri, Osmanlı Tarih Yazarlarında Toplumsal Sorumluluk Bilinci adıyla 2006 yılında Ankara'da basılmıştır.

Eser, giriş ve iki bölümden oluşmaktadır. Yazar eserin önsözünde Osmanlı tarih yazarlarının, tarih yazımında toplumu ne kadar önemsedikleri ve bunun kriterlerinin neler olduğunun tespiti üzerinde müstakil olarak çok az durulduğundan hareketle, ele almış olduğu konunun önem ve ciddiyeti üzerinde durmaktadır. Yazar bu önemli konuyu, tarih yazarlarının mukaddimelerindeki ifadelerinden yola çıkarak açıklamaya çalıştı̆̆ını belirtmektedir. Böylece okuyucunun, Osmanlı tarih yazarlarının yaşadıkları dönemin dili hakkında da bilgi sahibi olacağını düşünmüş olan yazar, söz konusu hususun yanı sıra çalışmasının Osmanlı tarihçileri hakkında genel bir bibliyografya sunduğuna işaret etmektedir. Zira burada Cumhuriyet döneminde Osmanlı tarih yazarlarını konu edinen Franz Babinger'in çeviri$\mathrm{si}^{2}$ ve Orhan Bayrak'ın ${ }^{3}$ hazırlamış olduğu müstakil iki çalışmanın varlığına değinen yazar, bu iki çalışmanın daha ziyade biyografik ve bibliyografik bilgiler içerdiğini, kısmen de Osmanlı tarih yazıcılığının oluşum ve gelişim evrelerini ele aldığını ifade etmektedir.

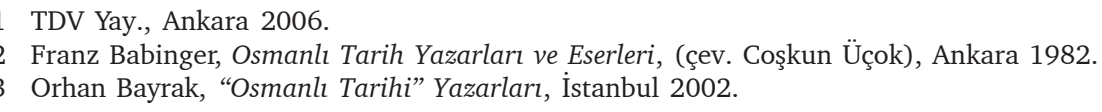


Yazar, giriş kısmında (s. 11-16) araştırmanın amacı, kapsamı ve metoduna dair okuyucuyu bilgilendirmekte, çalışmanın hedefini Osmanlı tarih yazarlarının kendi ifadeleri esas alınarak, Osmanlılarda tarihçi-toplum diyalogunun derecesini belirlemek ve tarihçilerin toplumsal kaygılarının eserlerinin muhteviyatını ne kadar etkilediğinin tespiti olarak ifade etmektedir.

Yazar yapmış olduğu çalışmanın bir başka örneğinin olmaması nedeniyle eserin planlanması esnasında bir hayli zorlandığından bahsetmekte bunun yanı sıra tarih yazarlarının toplumsal sorumluluk bilinçlerinin hangi kriterler çerçevesinde belirleneceğinin tespitinin de ayrıca bir zorluk olarak önüne çıtı̆̆ını dile getirmektedir.

Yazar Osmanlı tarih yazarlarının eserlerindeki tarihi, insanlara yararlı bir bilim olarak algılama, tarih bilinci kazandırma çabası, tarihin yararlarını kavratma gayretlerinin olup olmadığını yansıtan ifadelerinden hareketle bu kriterleri tespit ettiğini söylemektedir. Yazar tarafından belirlenen kriterler eserde şu şekilde sıralanmaktadır;

1. Tarih yazarının kendisini tanıtması, eserini kaleme alış sebebiyle ilgili olarak açıklamada bulunması,

2. Tarih yazarının muteber kabul ettiği tarih kitaplarından yararlanmış olduğunu söylemesi,

3. Toplumun alt ve üst düzey olmak üzere her kesimine yararlı olma kaygısı taşıdığııı beyan etmesi,

4. Tarihi geçmişten bir ibret alma vesilesi olarak görüp, toplumun bu kazanımı elde etmesine yardımcı olduğunu düşünme anlayışını ifade etmesi,

5. Tarihçinin gördüğü birtakım eksiklikleri giderme endişesi taşıdığını hissettirmesi ve bunu açıkça beyan etmesi,

6. Tarihçinin topluma yararlı olacak bir eseri kaleme alma isteğini belirtmesi,

7. Kendisinden önce hazırlanan eserlerin olumlu ve olumsuz yönleriyle ilgili olarak okuyucuyu bilgilendirmesi,

8. Hazırladığı eserinden okuyucunun faydalanmasını kolaylaştırmak maksadiyla fihrist, resim, harita, tablo vs. kullanması,

9. Arşiv belgelerini yaptığı işin doğruluğunu desteklemek bakımından kullandığını açılaması,

10. Hedef kitle olarak toplumun hangi kesimini seçtiğini belirtmesi,

11. Dil kaygısı taşıdığını ifade edip Osmanlı Türkçesiyle ve sade bir anlatımla eserini yazmayı tercih ettiğine dair açıklamada bulunması,

12. Kendisinde önceki tarih yazıcıllğını ve yazarlarını çeşitli yönlerden tenkit etmesi, 
13. Eserinde, başka milletlerin tarih ve tarihçiliği ile mukayesede bulunmas1,

14. Tarih ders kitapları olumlu veya olumsuz şekilde görüş beyan etmesi,

15. Toplumu doğru bilgilendirme için çaba sarf ettiğini, haberleri ve hadiseleri alırken dikkat ettiği hususları, muteber eserlerden yararlandığını belirterek aktarmaya çalışması,

16. Olabilecek hatalarından dolayı okuyucudan af dilemesi, okuyucuyu ciddiye aldığını ve önemsediğini göstermesi.

Yazar bu kriterleri verdikten sonra, "Tarih ve İnsan" ile "Tarihçi ve Toplum" adlı iki ayrı başlık altında bazı mülahazalarını okuyucuyla paylaşmaktadir.

Eserin birinci bölümünde Osmanlı Tarih Yazarlarının Mukaddimelerindeki Ífadeleriyle Tarih, Tarihçilik ve Toplum başlı̆̆ 1 altında ilk önce kronolojik olarak 80 adet Osmanlı tarihçisinin oldukça kısa biyografileri verilmiş, ardından da onların mukaddimelerinde yer alan toplumsal sorumluluk bilinciyle ilgili alıntılar, yine kendi ifadeleriyle kaydedilmiştir.

Burada incelenen Osmanlı tarih yazarları ise şunlardır; Oruç Bey, Şükrullah (ö. 1488), Tursun Bey (ö. 1499'dan sonra), Âş1kpaşa-zâde (ö. 1502'den sonra), Mehmed Neşrî (ö. 1520), Hadîdî, Kemâlpaşa-zâde (ö. 1534), Lütfi Paşa (ö. 1563), Taşköprülü-zâde Ahmed Efendi (ö. 1561), Mehmed Zaîm, Mustafa b. Celâl (Koca Nişancı) (ö. 1567), Mustafa Cenâbî (ö. 1590), Alâaddin Ali Dede el-Bosnavî (ö. 1598), Hoca Sadedin Efendi (ö. 1599), Gelibolulu Mustafa Âlî (ö. 1600), Mustafa Rumûzî Efendi, Selânikî Mustafa Efendi, Abdülganî-zâde Mehmed Nadirî (ö. 1626), Mehmed b. Mehmed (ö. 1640), Mehmed b. Mustafa Baldır-zâde (ö. 1650), Peçevî İbrahim Efendi, Abdullah Çelebî (Rıdvan Paşa-zâde), Kâtip Çelebî (ö. 1657), Kara Çelebi-zâde Abdülaziz (ö. 1658), Mehmed Hemdemî Solak-zâde (ö. 1657), Hasan Ağa, Hüseyin Hezarfen (ö. 1691), Ahmed b. Lütfullah Müneccimbaşı (ö. 17029, Naîma Mustafa Efendi (ö. 1716), Fındıklılı Silahdâr Mehmed Ăga (ö. 1723), Osman-zâde Ahmed Tâib (ö. 1724), Süleyman b. Şem'adânî-zâde (ö. 1779), Ahmed Bahâeddin Cizyedâr-zâde (ö. 1794), Ahmed Vâsıf Efendi (ö. 1806), Mehmed Sâdık Zaim-zâde (ö. 1823), Atâullah Mehmed Şâni-zâde, Mustafa Necib (ö. 1831), Mehmed Said Ferâizîzâde, Sahaflar Şeyhi-zâde Mehmed Es'ad (ö. 1848), Hâfız Hızır Efendi (ö. 1864), Hayrullah Efendi (ö. 1866), Tayyâr-zâde Atâullah Ahmed (ö. 1877), Mehmed Mazhar Fevzî (ö. 1878), Mehmed Şem’î (ö. 1882), Abdullatîf Subhî Paşa (ö. 1886), Eyüp Sabri Paşa (ö. 1890), Ahmed Râşid Paşa (ö. 1891), Ahmed Vefik Paşa (ö. 1891), Ahmed Cevdet Paşa (ö. 1895), Ah- 
med Lütfiî Efendi (ö. 1907), Mizancı Mehmed Murad Bey (ö. 1917), Ahmed Midhat (ö. 1912), Mehmed Şâkir Paşa (ö. 1913), Safvet Bey (ö. 1913), Mehmed Râif (ö. 1916), Ahmed Sâib (ö. 1918), Ali Râzî, Sâmi, Aziz ve Şevki Bey, Hasan Sırrî, Ali Reşâd Bey, Hüseyin Hıfzî, Mehmed Es'ad, Osman Hilmi, Ali Haydar Emir, Mehmet Tevfik, Mahmud Celâleddin Paşa, Ali Rıza Seyfi, Hayreddin Bey, Ali Fuad Bey, Avlonyalı Süreyya, Mahmud Es'ad Seydişehrî, Kâmil Paşa, Abdurrahman Şeref Efendi (1853-1925), Ali Seydî Bey (1870-1933), Efdaleddin Bey (1868-1957), Ahmed Refik (Altınay) (1882-1937), Ahmed Râsim (ö. 1932), Ahmed Hâmid-Mustafa Muhsin. (s. 17-200)

Çalışmanın ikinci bölümü olan Osmanlı Tarih Yazarlarının Toplumsal Sorumluluk Bilinçlerinin Değerlendirilmesi başlığında ise, ilk olarak Osmanlı tarih yazarlarının tarih eseri yazmak için ileri sürdükleri gerekçelerin tasnifi yapılmıştır. Eserde zikredilen gerekçeler ise şunlardır: Tarihe olan kişisel ilgi; yazar Osmanlı tarih yazarlarının genel olarak erken yaşlarından itibaren tarihe ilgi duyduklarını belirtmeleri ve bu nedenle sonraları da tarihle ilgili eserler okumaya ve ileri düzeyde tarih eserleri yazmaya sevk eden amillerin başında bu yönelimin geldiğini ifade etmektedir. Şahıs veya bir grubun yönlendirmesi; Osmanlı tarih yazarlarının eserlerini kaleme alırlarken ileri sürdükleri gerekçelerden birisi de kendilerinin teşvik edildikleri hususudur. Bu teşvikler kendilerinin değer verdikleri ilim erbabı, tarih-şinâs bir kimse veya bir cemaat tarafindan olabilmektedir. Resmi istek; Yazar, Osmanlı tarih yazarlarının bir kısmının, kendilerinden talepte bulunan idarecilerin tarih ilmine olan ilgilerini topluma yansıtmak arzusuyla, resmi istekleri eserlerinde zikretmek durumunda kaldıklarını ifade etmektedir. Toplumu bilgilendirme ve yararlı olma isteği; Yazar, Osmanlı tarih yazarlarının büyük bir kısmının mukaddimelerinde eserlerinin yazılma sebebi olarak topluma faydalı olmak düşüncesinde olduklarının açık ya da dolaylı ifadelerle dile getirdiklerini belirtmektedir. Tarih yazarının kendinden önce yazılmış olan Osmanlı tarihlerini beğenmemesi; Yazar burada Osmanlı tarih yazarlarının toplumsal sorumluluk bilincine işaret eden en önemli hususlardan birisinin de, onların toplumun doğru bilgilendirilmesini önemsemeleriyle alakalı olarak kendilerinden önce yaşayan tarihçileri örnek almaları ya da eleştiriye tabi tutmalarının olduğunu söylemektedir. Özellikle Mehmed Neşrî, Mustafa b. Celal, Mustafa Âlî, Hoca Sadeddin gibi bazı yazarların eleştiri hususlarını kısaca zikretmektedir.

Yazar bu bölümde ikinci olarak Osmanlı tarih yazarlarının toplumsal sorumluluk bilincinde tarih ögretiminin yeri konusunu incelemiştir. Burada genel olarak Osmanlı medreselerinde tarih öğretimine özel bir önemin at- 
fedilmediği belirtilmekte, ancak Tanzimat'tan sonra açılan mekteplerin müfredatlarında tarih öğretimine yer verildiği ifade edilmektedir. Buna ek olarak bu kısımda Osmanlı tarih yazarlarının tarih öğretimine ve tarih ders kitaplarına dair görüşleri zikredilmektedir.

Üçüncü olarak Osmanlı tarih yazarlarının batıya ve batı tarihçiliğine ilgileri ele alınmıştır. Yazar, burada Ahmed Midhat, Abdurrahman Şeref, Ali Reşad Bey, Ahmed Refik, Hayreddin Bey ve Ali Fuad Bey'in görüşlerine yer verdikten sonra Osmanlı tarihçilerinin Batı'ya ve oradaki tarihçiliğe ilgilerinin iki noktada odaklandığını belirtmektedir. Bunlardan birincisi; Tarihçilik alanında yaşanan gelişmelerin bilimsel anlamda önemsenmesi ve örnek alınmasıdır. İkincisi ise tarihçilikte her ne kadar tarafsızlık ön planda tutulması gerekse de, Batı'nın Osmanlı Devleti'nin aleyhinde olduğunun bilinmesi ve bunu doğal sonucu olarak toplumun bu duruma karşı bilinçlendirilmesi zaruretidir.

Son olarak ise Osmanlı tarih yazarlarında toplumsal sorumluluk bilincinin evreleri üzerinde durulmuştur. Burada yazar Osmanlı tarih yazarlarının toplumsal sorumluluk bilinçlerinin tespiti için başta verdiği kriterlerin bir değerlendirmesini yapmaktadır. Daha sonra da Avrupa'da örnekleri verilmiş olan kolektif tarih yazıcılı̆̆ının, Osmanlı tarih yazıcılığındaki örneği üzerinde durmaktadır. Tarih yazıcılığında gelinen son nokta olarak Tarih-i Osmânî Encümeni'ne ve kaleme aldırdığı Osmanlı tarihine kısaca değinmiştir. (s. 201-234)

Eser sonuç, geniş bir bibliyografya, ek ve dizinlerle sona ermiştir. (s. 235-255)

Eserin sonunda Ek kısmında 3 sayfa halinde Osmanlı tarih yazarlarının toplumsal sorumluluk bilincini tespit kriterleri bir çizelge halinde okuyucuya sunulmuştur.

Yazar Osmanlı tarih yazarlarının mukaddimelerinden yola çıkarak bir durum tespiti yapmıştır. Buna göre Osmanlı tarihçileri tarafından kaleme alınan tarih kitaplarının büyük kısmı her ne kadar devlet adamlarına sunulmuş olsa da, bu yazarların hiç bir zaman toplumu göz ardı etmedikleri ortaya çıkmıştır. Tanıtımını hazırladığımız Doç. Dr. Eyup Baş’ın bu araştırması, alanında ilk örnek olması ve yoğun emek isteyen bir konuya temas etmesi nedeniyle dikkate değer bir çalışmadır. 